bution to the culture of the community..$^{30}$ Nevertheless, the doctrine of unjust enrichment compels the conclusion that judicial relief should be available to the originator of material which has been appropriated. By the same token agencies are entitled to protection against blackmail and honest but unfounded claims. The present framework of common-law protection of "hot ideas" could probably be strengthened if litigation were discouraged through statutes similar to the federal copyright provisions, which impose reasonable attorneys' fees as part of the unsuccessful litigant's costs. ${ }^{3 x}$ In addition where the material is unsolicited the requirements of "concrete combination" and novelty should be strictly enforced against the possibility of invalid claims. However, agencies which actively solicit material from free lance professionals and amateurs should be held to more stringent standards of liability. Any other rule would encourage controversy and handicap just and effective judicial administration of the "hot idea" industries.

\title{
VERBAL ACTS AND IDEAS-THE COMMON SENSE OF FREE SPEECH
}

Conviction for a breach of the peace may conceal a threat to the right of freedom of speech. The only cases in which the United States Supreme Court has been confronted by the presence of both concepts ${ }^{\mathrm{I}}$ did not require full exposition of their possible inconsistency. But a recent Tllinois decision, City of Chicago v. Terminiello, ${ }^{2}$ brings the question into sharp relief.

This problem, like any other involving the right of free speech, necessitates an understanding of the reasons that some speech is protected while other speech is punishable. The protection of the First Amendment may be invoked only when the words used are intended to convey ideas. Even though hostile in nature, these words will be protected because the "[u]ltimate good desire is better reached by free trade in ideas-that the test of truth is the power of the thought to get itself accepted in the competition of the market. ..."3

${ }^{30}$ For a development of the theory that thoughts are protected not so much for considerations of value but as instances "of the more general right of the individual to be let alone," see Brandeis and Warren, The Right to Privacy, 4 Harv. L. Rev. 193, 204-5 (I890). For a suggestion that abstract ideas are unprotected because a mere abstraction is not of sufficient value to society, see Logan, Legal Protection of Ideas, 4 Mo. L. Rev. 239, 240 (r939). But see $36 \mathrm{Col}$. L. Rev. $1375,{ }_{376}$ (1936), noting Grombach Productions, Inc. v. Waring, 293 N.Y. 609,59 N.E. 2 d 425 (I944), for the suggestion that ideas are not given the status of property because of the benefits to society from their free dissemination.

${ }^{37}$ See Caruthers v. RKO Radio Pictures, Inc., 20 F. Supp. 906, 908-9 (N.Y., 1937). The applicable section of the Copyright Act is 35 Stat. 1084 (I909), I7 U.S.C.A. § 40 (1937).

I Two important free speech cases have involved breach of peace prosecutions: Cantwell v. Connecticut, 310 U.S. 296 (1940); Chaplinsky v. New Hampshire, 3I5 U.S. 568 (1942); see also Cox v. New Hampshire, 312 U.S. 569 (194I).

2400 IIl. 23,79 N.E. $2 \mathrm{~d} 39$ (x 948 ).

3 Schenck v. United States, 249 U.S. 47,52 (Igrg). 
The characteristic of speech, then, which merits special consideration is its ability to convey truth. Alexander Meiklejohn has called this the public interest in speech as opposed to the private interest: Speech of public interest is absolutely protected by the First Amendment, but speech of private interest may be reasonably regulated or punished. ${ }^{4}$ Words of idea-conveying nature, even though objectionable, will be protected because of the benefit to the public interest. But words of interest only to the individual will be punished when a different area of the public interest has been injured. Punishment follows according to what has been called the "normal criminal law of words."s For example, objectionable words may be punished because they are obscene and abusive or because they urge another to commit a crime.

Words of purely private interest may, of course, be so confined in their use as to preclude punishment. ${ }^{6}$ Thus, the defendant in the Terminiello case argued that his speech, made before an invited audience which had gained entrance to the meeting by presenting mailed cards of admission, was a private affair and could not have breached the public peace. In order to pass on the validity of such a claim, the courts must define the notion of a breach of the problic peace.

The presence of a statute applicable only to breaches in a public place makes the formulation easier to reach, although even in such cases it is frequently troublesome. ${ }^{7}$ Where the statute applies to both private and public places, a definitive test is more difficult to find. Some of the standards suggested in the cases depend on the number of people disturbed, ${ }^{8}$ others on whether the people present were invited. 9 Most courts, however, resort to an indefinite statement that the time, place, and circumstances must be taken into consideration. ${ }^{10}$

All these tests are inadequate because they fail to state the offense against the public which the breach of the peace prosecution is supposed to punish. This inadequacy may be avoided by an examination of the different injuries to the public concealed by the vague generic term "breach of the peace.". An example of the all-inclusive nature of the breach of peace action for the use of objectionable words is the court's finding in the Terminiello case that the defendant had breached the peace in five different ways: $I$ ) The defendant called members of the audience "scum," an abusive word." ${ }^{\text {II }}$ ) The defendant's "opprobrious, abu-

1 Meiklejohn, Free Speech and Its Relation to Self-government 63 (I948).

s Chafee, Free Speech in the United States 149 (I94I).

${ }^{6}$ People v. Monnier, 280 N.Y. 77 , 19 N.E. $2 \mathrm{~d} 789$ (1939) (abusive words used over a telephone held not a breach of the peace). People v. McCauliff, 267 N.Y. $58 \mathrm{r}$, I96 N.E. 590 (1935) (abusive words used by husband toward wife in their home held not breach of peace).

7State v. Weekly, 29 Ind. 206 (r867); Carwile v. State, 35 Ala. 392 (1860); Taylor v. State, $22 \mathrm{Ala}$. $15(\mathrm{x} 853)$. In all these cases the courts had to define a public place to establish the crime of affray, related to breach of the peace.

8 People v. Reid, r80 N.Y. Misc. 289, 40 N.Y.S. 2d 793 (r943).

9 Austin v. State, I24 S.W. 636 (Tex. Crim. App., Igro).

ro City of Chicago v. Terminiello, 332 Ill. App. I7, 74 N.E. 2d 45 (1947).

"City of Chicago v. Terminiello, 400 Ill. 23, 32, 79 N.E. 2d 39, 44 (1948). 
sive and insulting stories ... incited an actual breach of the peace within the auditorium." ${ }^{2} 3$ ) "[T] $]$ he defendant's conduct in scheduling an address in a large auditorium, invited a storm of protest... [which] resulted in innumerable acts of violence." ${ }^{3}{ }_{4}$ ) "As to the majority of the audience, defendant, by his provocative and inflammatory utterances ... instilled in them the fear of revolution, domination and murder by what he described as the criminal Jewish element in America...." ${ }_{14}$ 5) The defendant's "speech tended to incite the majority of his audience to immediate violence against the angry mob outside." +5

Of these grounds for conviction, the first comes closest to the historical pattern of a breach of the peace action. Abusive words have been punished because they tended to provoke a fight. ${ }^{16}$ Lewd, obscene, profane, libelous, and insulting or fighting words are punished because "their very utterance inflict injury or tend to incite an immediate breach of the peace." ${ }^{17}$ But this statement attributes to insulting words two different objectionable qualities-such words "injure" or "tend to incite an immediate breach of the peace." The element of injury characterizes the word as an act with the effect of a blow. Yet most courts justify punishment for breach of the peace on the sole ground that abusive and offensive words tend to incite an immediate breach of the peace by causing a fight. ${ }^{18}$

This dichotomy is also evident in another verbal crime, criminal libel. Punishment for this crime was first justified because libelous words tended to cause a breach of the peace. In modern cases, the breach of the peace is not necessarily considered; libelous words can be punished merely because they injure the object of the libel. The threat to the public peace is no longer needed as a justification. ${ }^{\text {x }}$

The modern justification sometimes used in criminal libel can perhaps be understood by realizing that an injury to reputation and character is more tangible than one to feelings or peace of mind. Peace of mind is easily disturbed, and angry words are frequently used. In the breach of peace actions the courts, by emphasizing the threat to public peace presented by a fight, have been able to contain within reasonable bounds ${ }^{20}$ the instances in which abusive words will be punished. ${ }^{2 x}$

sa Thid.

${ }^{4}$ Ibid., at 33,44 .

${ }^{23}$ Mbid.

${ }^{35}$ Ibid., at 33,45 .

${ }^{26}$ This is the rationale stated in Chaplinsky v. New Hamphsire, 315 U.S. 568 (1942).

${ }_{17}$ Mbid., at 572 quoting Chafee, op. cit. supra note 5 .

${ }^{18}$ State v. Steger, 94 W.Va. 576, II9 S.E. 682 (I923).

I9 Burdick, Law of Crime $\$ 785$ (1946); May, Law of Crimes $\S$ II5 (Sears's and Weihofen's ed., 1938), citing I9 A.L.R. I523 (1922).

${ }^{10}$ Ware v. Loveridge, 75 Mich. 488, 42 N.W. 997 (1889).

${ }^{2 x}$ It is not clear from the cases whether the threat of a fight in itself is a sufficient breach of peace or whether the threat of the fight must disturb the public represented by one or more on- 
The dual basis for the punishment of offensive words explains the courts' difficulty in determining just when the public has been disturbed. Under the tendency-to-provoke-a-fight rationale, the courts seek some member of the public at large who might have been disturbed..$^{23}$ Under the injurious-nature-of-thewords-themselves approach, the abused person himself is the "public."23

The second and third findings of breach of the peace in the Terminiello case are not easily fitted into the ordinary pattern of breach of the peace prosecution. In the third example the court intimated that the defendant should not have scheduled the meeting because he knew it would provoke others to breach the peace ${ }^{24-a}$ form of previous restraint. In the second example the court blamed the speaker for the intemperate reaction of his unfriendly listeners: a reaction not to abusive words directed at the listener, such as the word "scum," but to distorted propaganda aimed to persuade his audience.

The significant difference between conviction for using words like "scum" and conviction for the rest of the speech is illustrated in Cantwell v. Connecticul ${ }^{25}$ and Chaplinsky v. New Hampshire. ${ }^{26}$ In the Cantwell case the Catholic listeners were angered by the vilification of their religion by Cantwell, a Jehovah's Witness, and threatened to strike him. The court held that he was not guilty of common-law breach of the peace. His exaggeration and vilification were excesses of discussion and persuasion which a society interested in preserving freedom of speech had to accept. In the Chaplinsky case, calling a marshal a "damned Fascist" and "damned racketeer" was held to be a breach of the peace even though there was no evidence that the marshal was angered or tempted to strike Chaplinsky. The two cases dramatically point out the difference between the word as an act and the word as an idea. It is therefore desirable that the statute or ordinance be directed specifically at abusive and offensive words so that

lookers. See Morris v. District of Columbia, 3 I A. 2 d 652 (Mun. Ct. App. D.C., r943), where an insult to a single passenger by a taxicab driver was held to be disorderly conduct because it tended to cause a breach of the peace.

${ }^{2} \mathrm{~A}$ husband, finding his wife in a hotel room with another man, shot and killed him. The wife was held not guilty of a diversion tending to a breach of the peace. "Only the parties immediately concerned were disturbed thereby." City of Chicago v. Murray, 333 IIl. App. 233, 237, 77 N.E. 2d 452, 454 (I947).

${ }_{23}$ "We would be loath to hold that language which would insult a man, would not be insulting to a female, because by reason of her sex and gentler nature she would not resent it with blows." Benson v. State, 68 Ala. 513, 5I4 (188r).

Because a police officer is not expected to fight even when provoked, some courts, unlike the Supreme Court in the Chaplinsky case, have held that insulting an officer is not a breach of the peace. People v. Lukowsky, 94 N.Y. Misc. 500, 159 N.Y. Supp. 599 (rgr6); State v. Moore, r66 N.C. 37I, 8I S.E. 693 (r9I4). Contra: Pavish v. Meyers, I29 Wash. 605, 225 Pac. 633 (1924) (insulting an officer is a breach of the peace because it tends to lessen respect for law and order). People v. Fenton, ro2 N.Y. Misc. 43, I68 N.Y. Supp. 725 (I9I7); Elmore v. State, ${ }_{5}$ Ga. App. 46r, 83 S.E. 799. (I914).

34 The same argument has been used to justify statutes forbidding the display of red flags. People v. Burman, I54 Mich. I50, II 7 N.W. 589 (I908).
253 I0 U.S. 296 (I940).
${ }^{26} 3 \times 5$ U.S. 568 (1942). 
courts are not tempted to label the expression of unpopular ideas "breach of the peace."

The danger to free speech in a broader statute is that an opposition group has the power to create a situation tense and threatening enough to expose the speaker to a ready-made breach of peace prosecution. Rather than provoking a prosecution against the speaker, such action demands vigorous measures against the opposition. ${ }^{27}$ If the police are unable to manage opportunistic troublemaking, free-speech rights are meaningless.

The last two examples in the Terminiello case charge the speaker with instilling fears, anger, and hatred in his sympathetic listeners and with inciting them to immediate violence. The breadth of the breach of the peace action is indicated by the inclusion of incitement, generally an offense included in the criminal law of solicitations. ${ }^{28}$ But the propriety of such inclusion should be determined by reference not only to the law of solicitations but to the closely related law of attempts.

A solicitation is the mere urging of one person by another to commit a crime. The person solicited need not be at all responsive to the solicitation. He may reject it entirely. ${ }^{29} \mathrm{He}$ may be the one who discloses the crime to the authorities..$^{30}$ Still the solicitation has been held criminal. There is no talk of success, no talk of how close the solicitation may have come to bringing about the crime. An attempt, however, is a progression toward a crime which falls short of consummation but is still punishable. ${ }^{3 x}$ The acts of preparation must come close to success before they become criminal. ${ }^{32}$

If the court meant to apply the standards of the laws of solicitations and attempts, Terminiello may well be punished for a solicitation. But even though the ideas expressed may have been unpopular distortions, the speech could nevertheless have been considered of a sufficient idea-conveying nature to merit protection for its public interest. If this is so, the speech presents the problem of the protection of rights of free speech rather than the problem of punishment for criminal use of words. And the traditional control used in free speech cases is the clear and present danger test. ${ }^{33}$

${ }^{27}$ See Rebecca West's description of the pains taken by the London police to protect Fascist meetings from Communist attacks and Communist meetings from Fascist attacks. Miss West's articles also contain an informal report of a recent English case dealing with a breach of the peace prosecution for Anti-Semitic remarks. West, A Reporter at Large, 24 New Yorker, No. 24, at 24 (Aug. 7, I948); Tbid. No. 25, at 26 (Aug. I4, 1948).

${ }^{28}$ The crime is generally called "solicitation" rather than "incitement" in criminal-law terminology. Perhaps the word "incitement" is better used to describe words which provoke an attack against the speaker.

29 State v. Hampton, 2 10 N.C. 283 , I86 S.E. 25 (x936) (the defendant was held guilty of a crime even though his solicitation to burn a neighbor's dwelling was spurned).

${ }^{30}$ State v. Avery, 7 Conn. 266 (I828) (the defendant wrote a letter to another man's wife soliciting her to commit adultery with him; the information seems to have been sworn to by the wife).

${ }^{3 x}$ May, Law of Crimes $\S$ I3० (Sears's and Weihofen's ed., 1938).

32 People v. Murray, $x_{4}$ Cal. ${ }^{59}$ ( 1859 ).

33 '"[T] $]$ he 'clear and present danger' language of the Schenck case has afforded practical 
Interestingly enough, the clear and present danger test had its source in the law of attempts, ${ }^{34}$ since it was first enunciated in Schenck $v$. United States. ${ }^{35}$ In the Schenck case the prosecution was for a violation of the Espionage Act of x9I7. Section 3 of this Act ${ }^{36}$ was couched in terms of attempts; it described no verbal stage of the crime. As Justice Sanford later stated in Gitlow v. New York, ${ }^{37}$ the clear and present danger test was used in the Schenck case to determine whether the verbal acts came close enough to the acts described in the statute to be punishable.

A different situation is presented when the statute specifically makes unlawful certain verbal acts, such as inciting (soliciting) people to violent overthrow of the government. The latter type of statute fixes the level at which verbal acts are unlawful and does not permit the application of the clear and present danger test in the same manner as in the Schenck case. This type of statute is equivalent to the criminal law of solicitation, which punishes the mere urging to crime without reference to success. Therefore, as Justice Brandeis pointed out in Whitney ข. California ${ }^{38}$ the clear and present danger test needed extension to ward off the damaging blow to freedom of speech which could be struck by a simple legislative determination that use of words under any circumstances was unlawful. To avoid this encroachment, the standard was reframed to test the validity of a statute labeling a verbal act as unlawful: If there is no clear and present danger of substantive evil presented by the use of the words, then to call such speech unlawful is unconstitutional..$^{39}$

When, therefore, the words of solicitation appear to have public interest or idea content, the ordinary law of solicitation collides with the extended variation of the clear and present danger test. Which law shall control ${ }^{40}$ The answer

guidance in a great variety of cases in which the scope of constitutional protections of freedom of expression was in issue." Bridges v. California, 3I4 U.S. 252, 262 (I941).

34 "But as this court has declared . . . the test to be applied-as in the case of criminal attempts and incitements-is not remote or possible effect. There must be the clear and present danger." Brandeis, J., dissenting in Schaefer v. United States, 25I U.S. 468, 486 (I920); Riesman, Civil Liberties in a Period of Transition, 3 Pub. Policy 33, 38 (I942); Chafee, op. cit. supra note 5 , at $23,46,47,39$.

$$
{ }_{35}^{349} \text { U.S. } 47 \text { (1919). } \quad{ }^{36} 40 \text { Stat. } 219 \text { (I9I7), } 50 \text { U.S.C.A. § } 33 \text { (1928). }
$$

37 "[It] was manifestly intended, as shown by the context, to apply only in cases of this class, and has no application to those like the present, where the legislative body itself has previously determined the danger of substantive evil arising from utterances of a specified character." 268 U.S. 652, 67I (1925). The difference between the two situations has been pointed out in Dunne v. United States, r3 $_{3}$ F. $2 d$ 137 (C.C.A. 8th, 1943), and Commonwealth v. Lazar, 103 Pa. Super. 417 (I93I).

${ }^{38} 274$ U.S. 357 (1927).

39 See Thornhill v. Alabama, 3 ro U.S. 88 (1940); Herndon v. Lowry, 30I U.S. 242 (1937); De Jonge v. Oregon, 299 U.S. 353 (r937).

${ }^{40}$ Holmes seems to have looked only to the law of attempts as the source of the clear and present danger test, overlooking the fact that there is a clash between the law of solicitation and the extended variation of the test. Gitlow v. New York, 268 U.S. 652, 673 (1925); Abrams v. United States, 250 U.S. 6r6, 628 (1919). Chafee follows the Holmes view. He cites Commonwealth v. Peaslee, 177 Mass. 267,59 N.E. 55 (IgOI), an attempt case, as an early statement by Holmes of the clear and present danger test. Chafee, op. cit. supra note 5, at $39 \mathrm{I}$. 
depends on the degree to which the words constitute dissemination of ideas rather than incitement to crime. The public-private criterion will determine which legal context, criminal solicitation or freedom of speech, the words will evoke..$^{\text {I }}$ The distinction is not easy to make. In the Whitney case Justice Brandeis attempted to differentiate between advocacy and incitement, intimating that they are far apart..$^{2}$ Advocacy of ideas is useful to society and must be safeguarded, while incitement may be punished. But in one sense all words are incitements. The choice of punishment for solicitation or protection for advocacy under the clear and present danger test will depend on how receptive the courts are to the public-interest, idea-conveying nature of the words.

The application of this analysis to breach of the peace prosecutions is important because the dormancy of the law of solicitations has prompted reliance on catch-all breach of the peace statutes. In the absence of a concerted effort by the states to codify the common law of solicitation, ${ }^{43}$ it may be expected that a breach of the peace prosecution will be brought against a speaker who incites his listeners to violence. 44 But such a prosecution need not present any special danger to freedom of speech. 45 If the words are deserving of protection, the extended phase of the clear and present danger test can be incorporated into a breach of peace trial. If the words are exclusively words of incitement, they are a breach of the peace when uttered and will be punished accordingly. The burden is placed on the judge and jury to keep open minds, to reject the impulse to label unpopular advocacy as incitement. The burden is on the speaker to advocate rather than incite if he wishes to be protected. ${ }^{6}{ }^{6}$ The burden is on the law to work out reasonable methods by which incitements can be punished and advocacy protected. One step in answering all three challenges would be to break down the sweeping breach of peace ordinances into carefully phrased elements directed at particular offenses. This partial solution attacks the problem at its most accessible level by aiding the courts in the recognition of free speech situations in their proper perspective and in the application of appropriate controls.

${ }^{4}$ Two New York cases reveal how the judge's reaction to the words as abusive or persuasive may control the result. People v. McWilliams, 22 N.Y.S. 2d 57 I (I940); People v. Downer, 6 N.Y.S. $2 d 566$ ( 1938$)$.

12 Whitney v. California, 274 U.S. 357 (I927).

43 Curran, Solicitation: A Substantive Crime, I7 Minn. L. Rev. 499 (I933).

41 People v. Most, I7I N.Y. 423, 64 N.E. I75 (I902).

45 Thurman Arnold suggests that "the making of incendiary speeches and the publication of anti-social doctrine are more logically classified under the power to punish common law crimes than under solicitation or attempt." Arnold, Criminal Attempts-The Rise and Fall of an Abstraction, 40 Yale L. J. 53 (1930). The suggestion seems to be that such speeches are punishable as breaches of the peace.

${ }_{46}^{6}$ "Words are not only the keys of persuasion, but the triggers of action, and those which have no purport but to counsel the violation of law cannot by any latitude of interpretation be a part of that public opinion which is the final source of government in a democratic state." Masses Publishing Co. v. Patten, 244 Fed. 535, 540 (D.C. N.Y., 19I7). 